\title{
Work Context and Stress Symptoms in Basic Education Teachers
}

\author{
Valquíria Souza de Oliveira de Medeiroㅁ, Vinícius Renato Thomé Ferreira ${ }^{2}$, \\ Naiana Dapieve Patias ${ }^{3}$, Vanessa Rissi ${ }^{2}$, Márcia Fortes Wagner ${ }^{2}$, Vanessa Keche ${ }^{1}$ \\ ${ }^{1}$ Private Office, Passo Fundo, Brazil \\ ${ }^{2}$ Psychology Program at IMED, Passo Fundo, Brazil \\ ${ }^{3}$ Psychology Program at Federal University of Santa Maria (UFSM), Santa Maria, Brazil \\ Email: vinicius.ferreira@imed.edu.br
}

How to cite this paper: Medeiro, V. S. de O. de, Ferreira, V. R. T., Patias, N. D., Rissi, V., Wagner, M. F., \& Keche, V. (2019). Work Context and Stress Symptoms in Basic Education Teachers. Psychology, 10, 2038-2050.

https://doi.org/10.4236/psych.2019.1015131

Received: November 11, 2019

Accepted: December 20, 2019

Published: December 23, 2019

Copyright $\odot 2019$ by author(s) and Scientific Research Publishing Inc. This work is licensed under the Creative Commons Attribution International License (CC BY 4.0).

http://creativecommons.org/licenses/by/4.0/

\begin{abstract}
The teaching work records a scenario of environmental, organizational and interpersonal precariousness that contribute to the emergence of stress. The aim of this study was to investigate the correlation between work context and stress symptoms in elementary school teachers from public schools. It was a descriptive, correlational and cross-sectional study, whose sample was 196 teachers. Were used a sociodemographic survey, the Perceived Stress Scale (PSS), the Stress Symptom Intensity Survey (LIS-E) and the Work Context Assessment Scale (EACT). The mean stress symptoms were compatible with the general population; correlations between stress symptoms and work context for both instruments were weak. The work organization factor was assessed as moderate/critical, which indicates the need for short- and medium-term interventions. The socio-professional relations and working conditions obtained satisfactory evaluation. These results allow us to point out important aspects of programs for improving the organization of teaching work.
\end{abstract}

\section{Keywords}

Teachers, Work, Work Organization, Occupational Stress, Elementary School

\section{Introduction}

Work, at the same time, constitutes itself as a privileged space for the construction of identity, relationships, and enables experiencing situations that cause suffering and illness (Dejours, 1988). Teachers are not immune to the harmful 
capacity of work (Vale \& Aguillera, 2016). Studies have characterized teachers' health and illness conditions and confirm high prevalence of behavioral symptoms and health-related complaints (Gontijo, Silva, \& Innocente, 2013). The number of leaves of work due to mental illness has been progressively growing (Macaia \& Ficher, 2015). Emotional exhaustion and stress are conditions often identified in teachers, along with voice disorders and musculoskeletal disorders (Baião \& Cunha, 2013). In addition to individual and personality factors, those related to the work context (work organization, socio-professional relations and working conditions, Mendes \& Ferreira, 2008), are considered important predictors of illness (Dalcin \& Carlotto, 2017), as they are causing stress symptoms.

Stress symptoms have been frequently reported in the literature in teachers: emotional exhaustion, insomnia, headaches, mood swings, musculoskeletal pain and hopelessness (Ceballos \& Santos, 2015; Rey, Extremera, \& Pena, 2016). Stress is characterized by a series of changes that occur in the body, as a result of environmental pressures that the subject cannot cope effectively. Its development occurs in phases, so that in a first stage, called the alert phase, there is a rapid change in organs such as liver, spleen, thymus, erosion of the digestive tract and loss of muscle tone; the second stage, resistance, is a period marked by the organism's attempt to rediscover its homeostasis; if rebalancing is not possible, the near-exhaustion begins, with worsening of the initial symptoms; and later, exhaustion occurs, with symptoms very similar to that of the first phase, however, leading the organism to illness (Freitas \& Facas, 2013; Goulart \& Lipp, 2008; Kock, Biazi, \& Bennedetto, 2015; Martins \& Honorio, 2014; Souza \& Rozemberg, 2013). When it occurs in the work context, stress includes discomfort, feelings of tension, exhaustion, frustration, and unpleasant emotional state (Hirschle, Gondim, Alberton, \& Ferreira, 2019), being a risk factor for cancer, major depressive disorder, metabolic syndrome, chronic fatigue syndrome, sleep disorders, diabetes and burnout (Silva, Bolsoni-Silva, \& Loureiro, 2018; Dalcin \& Carlotto, 2017), and impair performance and interpersonal relationships.

Factors associated with stress in teachers are excessive working hours, large class sizes, low salaries, student and parent relationship problems, and student indiscipline (Pereira, Teixeira, Pelegrini, Meyer, Andrade, \& Lopes, 2014; Silveira, Enumo, Paula, \& Batista, 2014). If the teacher works in the context of public schools and the greater the number of students, hours worked and teaching time, working conditions and the general assessment of quality of life are worse (Dalcin \& Carlotto, 2017).

Differences between educational levels, educational policies, standards and management models, are among the contextual factors related to teaching (Dalcin \& Carlotto, 2017), which require greater attention from researchers, due to their likely association with teachers' illness. In Brazil, the last few years have been surrounded by important educational reforms, while the number of teachers away from work has increased (Piolli, Silva, \& Heloani, 2015; Macaia \& Ficher, 2015). 
The main changes resulting from educational reforms produced the establishment of an institutional assessment system based on the administrative and technical agility and on goals and performance indicators. Management practices were adopted in the public educational context, in order to control the teachers' productive performance. These changes have been reported to imply greater competition among peers, individualism and competition, which is related to the meritocratic management model adopted and generates aversive feelings in teachers (Piolli, Silva, \& Heloani, 2015; Piolli, 2013). Another significant change was the extension in Brazil of the elementary school time from eight to nine years, as well as its subdivision into two cycles, the first, initial grades (grades 1 to 5), and the second, final grades (grades 6 to 9), which may have negatively impacted student performance and performance. The impossibility of students to fail in the first three years causes problems in the following grades generating delays. This aspect tends to cause discomfort to teachers, who are blamed for not reaching the aimed educational objectives (Jacomini, 2010).

The existence of two educational phases in basic education considers that the initial grades are structured so that the same teacher is responsible for the entire curriculum, using more playful techniques, and the relationship with students presumes affection and closeness. In general, these teachers are undergraduate in pedagogy or magisterium. Higher stress levels are common in these initial grades, as teachers are beginning their careers (Prati \& Eizirik, 2006). In turn, the teachers of the final grades work in more classes, address a specific subject and have training in the area in which they work. Its relationship is different, considering the phase of adolescence of students, which is characterized by a search for peer proximity and distance from adults. Likewise, adolescents address the opposition of rules and the search for identity (Pereira \& Silveira, 2017; Cartaxo \& Martins, 2014).

The objective was to investigate the association between work context and stress symptoms in teachers of municipal public elementary schools. It was compared stress levels among the group of teachers in the initial grades and final grades.

\section{Method}

This research was a cross-sectional quantitative study, with correlational and descriptive design.

\subsection{Participants}

The sample consisted of 196 teachers from 44 municipal schools, 180 women and 16 men, aged 18 or older (average $=46.9$; $\mathrm{SD}=7.6$ ) who were recruited by convenience (Baptista \& Campos, 2016). Inclusion criteria were public elementary school teachers, men and women, from the school network of a Brazilian municipality. Teachers who did not complete the instruments and who were only in administrative activities were excluded. 


\subsection{Data Collection}

For data collection, were used the following instruments:

Sociodemographic survey: assessed the participant's gender, age, year of practice, length of professional practice, educational background, etc.

Work Context Assessment Scale (EACT): assess work context, with 31 items subdivided into work organization (11 items), socio-professional relations (10 items) and working conditions (10 items) (Mendes \& Ferreira, 2008). To perform the EACT analysis, the average of the three factors that make up the instrument was calculated and subsequently interpreted from the reference values: from 0 to 2.29 satisfactory context; from 2.3 to 3.69 moderate/critical context; and values above 3.7 severe context (Mendes \& Ferreira, 2008).

Stress Symptoms Intensity Survey (LIS-E): self-assessment tool that aims to identify the intensity of stress symptoms, consisting of 34 questions on a 5-point Likert scale, where the score ranges from 0 (no symptoms) to 4 (higher presence of symptoms). Psychometrical properties showed a KMO index $=0.96$ and Cronbach's alpha of 0.9 (Ferreira, 2015).

Perceived Stress Scale (PSS): evaluate self-perception of stress with 14 questions ranging from 0 to four $(0=$ never; $1=$ almost never; $2=$ sometimes; $3=$ almost always and 4 =always). The total scale is the sum of the scores and the scores may range from zero to 56, punctuating the stress level at the time of assessment (Luft, Sanches, Mazo, \& Andrade, 2007), and was used Brazilian adaptation. We chose to use the PSS because LIS-E was being in validation.

For the application of the instruments, the school principals were contacted to schedule the day and time for the researchers to visit. The teachers were gathered in a room in their respective work schools, where the researchers explained the research and invited them to participate and explained the study. After agreeing, the Informed Consent Form (TCLE) was signed, signed in two copies, and then the data collection instrument, starting with the socio-demographic questionnaire. The collections were carried out from July 2017 to July 2018.

\subsection{Data Analysis}

Data were organized for descriptive and inferential analysis of the sample, presenting frequencies, means and standard deviations. Non-parametric tests (Mann-Whitney and Spearman correlation) were used, considering that the instrument data did not present normal distribution (Dancey \& Reidy, 2013). The level of statistical significance was $p \leq 0.05$.

\subsection{Ethical Issues}

The research was guided by Brazilian Ethics resolutions 466/2012 and 512/2016, which regulates research with human beings, and approved by Research Ethics Committee (CAAE 2.014.441). Participants were assured of anonymity and freedom to leave the investigation at any time during the research, achieved by 
signing the Informed Consent Form (TCLE). The research was approved by the municipal education department of the municipality to which the schools belong. This study was funded by Brazilian CNPq Council (National Council for Scientific and Technological Development), by Universal Funding 01/2016, process number 421252/2016-2.

\section{Results}

The sample of teachers was composed by 180 women $(91.8 \%)$ and 16 men $(8.2 \%)$, with a predominant age of 46 years or older $(n=113 ; 57.7 \%)$. Married or in stable union were predominant $(\mathrm{n}=124 ; 63.3 \%)$, the Christian $(\mathrm{n}=170$; $86.7 \%)$, and with family income of 3 to 6 minimum wages $(n=83 ; 42.3 \%)$. In the initial grades, 130 teachers participated (66.3\%), and final grades, 66 (33.7\%). Regarding the level of education, 154 (78.6\%) have specialization; the predominant working time was 15 years or more of teaching $(n=129 ; 65.8 \%)$, and work at the school between 0 and 4 years and 11 months $(n=52 ; 26.5 \%)$. Table 1 shows complete information of the participants.

The total stress symptoms showed in Table 2 indicated a mean of 21.63 points. In the first grades the average of stress was 21.95 and final grades, 21.03, with no statistical difference. The general average of the LIS-E was 25.33, first grades reached 26.05 and final grades, 23.92, with no statistical difference.

The total score of EACT indicates that the work context was rated as moderate/critical, although without statistical difference (see Table 3). Similarly, the evaluation of the initial and final grades indicated moderate/critical classification. For the EACT Work Organization factor, both the general classification, as well as the evaluation of the initial and final grades presented a moderate/critical context, in the Socio-Professional Relations factor, the evaluation was considered satisfactory both in the total average and in the initial and final grades, and in Conditions of Work, the total mean was classified as satisfactory; in the initial series presented satisfactory classification and in the final, moderate/critical.

Almost all EACT items presented higher averages in the final grades, indicating greater impairment for this group. The ones that presented statistically difference in Work organization were the items 2-Tasks are fulfilled with deadline pressure (first grades $M=2.85$; final grades $M=3.25 ; p=0.02$ ), with moderate classification/criticism for both; 7-Expected results are unrealistic (first grades $M=2.55$; final grades $M=2.90 ; p=0.01$ ), both moderate/critical; 8 -There is division between who plans and who executes (first grades $\mathrm{M}=2.68$ final grades $\mathrm{M}=3.14 ; p<0.01$ ), both moderate/critical, and 9-The tasks are repetitive (first grades $\mathrm{M}=2.89$ and final grades $=3.19 ; p=0.03$ ), classified as moderate/critical. 25-Furniture in the workplace is inadequate (first grades $\mathrm{M}=2.35$, final grades $\mathrm{M}=2.78 ; p=0.01$ ), both classified as moderate/critical and question 26-The working tools are insufficient to perform the tasks (first grades $\mathrm{M}=2.59$, final grades $\mathrm{M}=3.06 ; p<0.01)$, classified as moderate/critical. 
Table 1. Description of the participants.

\begin{tabular}{|c|c|c|c|c|c|c|}
\hline \multirow{2}{*}{ Variable } & \multirow{2}{*}{ Description } & \multicolumn{2}{|c|}{ Initial grades } & \multicolumn{2}{|c|}{ Final grades } & \multirow{2}{*}{$\begin{array}{c}\text { Total } \\
\%\end{array}$} \\
\hline & & Frequency & $\%$ & Frequency & $\%$ & \\
\hline \multirow[t]{2}{*}{ Sex } & Woman & 125 & $69.40 \%$ & 55 & $30.60 \%$ & $91.8 \%$ \\
\hline & Man & 5 & $31.20 \%$ & 11 & $68.80 \%$ & $8.2 \%$ \\
\hline \multirow[t]{4}{*}{ Age } & 18 - 25 years 11 months & 1 & $50.00 \%$ & 1 & $50.00 \%$ & $1.0 \%$ \\
\hline & 26 - 35 years 11 months & 12 & $85.70 \%$ & 2 & $14.30 \%$ & $7.1 \%$ \\
\hline & 36 - 45 years 11 months & 44 & $65.70 \%$ & 23 & $34.30 \%$ & $34.2 \%$ \\
\hline & 46 years and more & 73 & $64.60 \%$ & 40 & $35.40 \%$ & $57.7 \%$ \\
\hline \multirow{6}{*}{$\begin{array}{c}\text { Academic } \\
\text { training }\end{array}$} & Incomplete graduation & 1 & $100.00 \%$ & 0 & $0.00 \%$ & $0.5 \%$ \\
\hline & Graduation & 15 & $68.20 \%$ & 7 & $31.80 \%$ & $11.2 \%$ \\
\hline & Incomplete specialization & 4 & $100.00 \%$ & 0 & $0.00 \%$ & $2.0 \%$ \\
\hline & Specialization & 102 & $66.20 \%$ & 52 & $33.80 \%$ & $78.6 \%$ \\
\hline & Incomplete Master degree & 1 & $50.00 \%$ & 1 & $50.00 \%$ & $1.0 \%$ \\
\hline & Master degree & 6 & $50.00 \%$ & 6 & $50.00 \%$ & $6.1 \%$ \\
\hline \multirow{4}{*}{$\begin{array}{c}\text { Time } \\
\text { working } \\
\text { as teacher }\end{array}$} & $0-4$ years 11 months & 4 & $80.00 \%$ & 1 & $20.00 \%$ & $2.6 \%$ \\
\hline & 5 - 9 years 11 months & 10 & $62.50 \%$ & 6 & $37.50 \%$ & $8.2 \%$ \\
\hline & $10-14$ years 11 months & 31 & $72.10 \%$ & 12 & $27.90 \%$ & $21.9 \%$ \\
\hline & 15 years and more & 83 & $64.30 \%$ & 46 & $35.70 \%$ & $65.8 \%$ \\
\hline \multirow{4}{*}{$\begin{array}{c}\text { Time } \\
\text { working } \\
\text { at school }\end{array}$} & $0-4$ years 11 months & 55 & $72.40 \%$ & 21 & $27.60 \%$ & $38.8 \%$ \\
\hline & 5 - 9 years 11 months & 19 & $54.30 \%$ & 16 & $45.70 \%$ & $17.9 \%$ \\
\hline & $10-14$ years 11 months & 33 & $63.50 \%$ & 19 & $36.50 \%$ & $26.5 \%$ \\
\hline & 15 years and more & 19 & $65.50 \%$ & 10 & $34.50 \%$ & $14.8 \%$ \\
\hline \multirow{5}{*}{$\begin{array}{c}\text { Marital } \\
\text { status }\end{array}$} & Not married & 22 & $59.50 \%$ & 15 & $40.50 \%$ & $18.9 \%$ \\
\hline & Married/Stable union & 82 & $66.10 \%$ & 42 & $33.90 \%$ & $63.3 \%$ \\
\hline & Divorced & 20 & $69.00 \%$ & 9 & $31.00 \%$ & $14.8 \%$ \\
\hline & Widowers & 5 & $100.00 \%$ & 0 & $0.00 \%$ & $2.6 \%$ \\
\hline & Other & 1 & $100.00 \%$ & 0 & $0.00 \%$ & $0.5 \%$ \\
\hline \multirow[t]{5}{*}{ Religion } & Christian & 114 & $67.10 \%$ & 56 & $32.90 \%$ & $86.7 \%$ \\
\hline & Spiritualistic & 14 & $82.40 \%$ & 3 & $17.60 \%$ & $8.7 \%$ \\
\hline & Mormon & 0 & $0.00 \%$ & 1 & $100.00 \%$ & $0.5 \%$ \\
\hline & No one specific & 1 & $50.00 \%$ & 1 & $50.00 \%$ & $1.0 \%$ \\
\hline & Not answer & 0 & $0.00 \%$ & 2 & $100.00 \%$ & $1.0 \%$ \\
\hline \multirow[t]{6}{*}{ Familial income } & 0 - 1.9 minimum wage & 0 & $0.00 \%$ & 1 & $100.00 \%$ & $0.5 \%$ \\
\hline & 2 - 2.9 minimum wage & 12 & $80.00 \%$ & 3 & $20.00 \%$ & $7.7 \%$ \\
\hline & 3 - 5.9 minimum wage & 55 & $66.30 \%$ & 28 & $33.70 \%$ & $42.3 \%$ \\
\hline & 6 - 9.9 minimum wage & 41 & $64.10 \%$ & 23 & $35.90 \%$ & $32.7 \%$ \\
\hline & $10-14.9$ minimum wage & 19 & $70.40 \%$ & 8 & $29.60 \%$ & $13.8 \%$ \\
\hline & 15 minimum wage and more & 3 & $60.00 \%$ & 2 & $40.00 \%$ & $2.6 \%$ \\
\hline
\end{tabular}

Source: data. 
Table 2. Comparative group of initial and final grade teachers to evaluate stress symptoms.

\begin{tabular}{ccccccccc}
\hline & \multicolumn{2}{c}{ Total } & \multicolumn{2}{c}{ First grades } & \multicolumn{2}{c}{ Final grades } & \multicolumn{2}{c}{ Mann-Whitney } \\
\cline { 2 - 9 } & Mean & SD & Mean & SD & Mean & SD & U & $p$ \\
\hline PSS & 21.63 & 7.98 & 21.95 & 8.11 & 21.03 & 7.67 & 3816 & 0.27 \\
LIS-E & 25.33 & 16.52 & 26.05 & 16.38 & 23.92 & 16.70 & 3889 & 0.37 \\
\hline
\end{tabular}

Source: data.

Table 3. Comparison of the averages in different grades of EACT.

\begin{tabular}{ccccccccc}
\hline & \multicolumn{2}{c}{ Total } & \multicolumn{2}{c}{ First grades } & \multicolumn{2}{c}{ Final grades } & \multicolumn{2}{c}{ Mann-Whitney } \\
\cline { 2 - 9 } & Mean & SD & Mean & SD & Mean & SD & U & $p$ \\
\hline Work organization & 2.81 & 0.77 & 2.68 & 0.79 & 3.08 & 0.71 & 309.5 & 0.15 \\
Socio professional relations & 2.21 & 0.95 & 2.25 & 0.93 & 2.21 & 1.03 & 376.5 & 0.72 \\
Work conditions & 2.24 & 0.87 & 2.12 & 0.91 & 2.48 & 0.81 & 287.5 & 0.07 \\
Total & 2.60 & 0.71 & 2.36 & 0.76 & 2.61 & 0.77 & 3695 & 0.15 \\
\hline
\end{tabular}

Source: data.

The correlations were weak between stress symptoms and work context (Spearman's rho): between LIS-E and PSS, relating them to the Work organization factor was 0.39; LIS-E and Socio-professional relations was 0.32 and with PSS 0.27; between LIS-E and Working conditions 0.31 and with PSS 0.26; correlation between LIS-E and EACT was 0.39 and with PSS was 0.36. Considering the stress tests and school time, profession time, classroom hours and age, weak correlations were found, ranging from 0.13 to 0.06 . The correlation between total EACT and Labor organization, Socio-professional relations and Working conditions factors with school time, profession time, classroom hours and age were weak, ranging from -0.01 to 0.13 . LIS-E and PSS showed a strong correlation (0.78), and these tests and EACT correlations showed moderate to strong between factors, ranging from 0.44 (Labor organization and Working conditions, moderate) to 0.86 (socio-professional relations and EACT, strong).

\section{Discussion}

The sample presented consisted of $91.8 \%$ of women, which is consistent with most studies conducted with elementary school teachers, in which the male population is reduced, at least in the Brazilian context. The presence of women in teaching gradually reverses as the years of education increase, and upon reaching higher education, the preponderance of men is higher (Dalagasperina \& Monteiro, 2014; Rodrigues, Paula, \& Silveira, 2017; Silveira, Enumo, Paula, \& Batista, 2014; Valente, Botelho, \& Silva, 2015). Even though this sample is non-random, it is compatible with the gender distribution scenario among elementary school teachers identified in literature.

The evaluation of stress symptoms had PSS mean 21.63 , close to that men- 
tioned in the translation and validation study for the Brazilian general population (21.37 points, Luft, Sanches, Mazo, \& Andrade, 2007), and for the LIS-E (25.33 points). Similar stress levels to the general population may be related to a moderately stressful environment (Gutierrez, 2016; Koga et al., 2015; Paschoal \& Tamayo, 2004). Even if the teaching profession has risk factors linked to the presence of stress, the teacher's perception plays a major role in how it will deal with environmental pressures, whether or not it develops symptoms of stress. When facing environmental pressures, the individual can overcome adversity without generating illness (Hirschle, Gondim, Alberton, \& Ferreira, 2019). Satisfactory (positive) perception about Socio-professional relationships at work, as occurring in this sample, tends to act as a predictor of well-being at work and also to represent a protective factor regarding workers' mental health. Social support from interpersonal work relationships (Birolim, Mesas, González, Santos, Haddad, \& Andrade, 2019) may contribute to lower stress levels among teachers. The greater the satisfaction with peer relationships, the lower the levels of emotional exhaustion, depersonalization, professional fulfillment, and burnout (Dalcin \& Carlotto, 2017).

There was no statistical difference in stress between PSS and LIS-E averages considering first and final grades. It is possible that both beginning and final grade teachers are encountering similar difficulties with work structuring, workload, economic factors, troubled student relationships, elements that may be related to the approximation of scores obtained on stress scales, affecting the two groups similarly (Gouveia, 2016; Pereira et al., 2014; Scandolara et al., 2015), although the scores are close to that of the general population.

The classification of work context as moderate/critical indicates a borderline situation and requires short- and medium-term interventions, due to the risk of aggravation of suffering, given the continuous exposure to risks (Mendes, 2007). The data revealed the presence of higher EACT scores in the final grade teachers. In this cycle there is a gradual change of students regarding motivation to learn, which causes difficulties at work. The daily challenge of trying to keep their students interested and planning lessons that are attractive often ends up not achieving the expected effect and generates feelings of frustration and discouragement in teachers (Caldas \& Hübner, 2001). Behavioral issues between students and teachers correspond to one of the main difficulties faced in teaching. Often teachers are unable to handle class behavior, which generates a sense of helplessness and displeasure at work (Barbosa, Campos, \& Valentim, 2011; Freitas \& Facas, 2013; Gutierréz, 2017; Tostes et al., 2018; Weber, Leite, Stasiak, Santos, \& Forteski, 2015). Final grade teachers may suffer greater pressure and demand for results for the accountability of education professionals for student performance (Vieira, Vidal, \& Nogueira, 2015). The work pace of teachers from 5th to 9th grade (Gouveia, 2016; Vieira, Vidal, \& Nogueira, 2015; Zibetti \& Pereira, 2010) may also contribute to the higher score in this item, with greater pressure on final grade teachers (Arvidsson, Håkansson, Karlson, Björk, \& Persson, 2016). 
The socio-professional relations presented satisfactory evaluation. A good level of interpersonal and professional relationships in the teaching work context can favor the workers' quality of life. On the other hand, it is possible to observe the association between the poor quality of relationships with feelings of dissatisfaction, frustration and demotivation at work, which are generally related to burnout development (Carlotto et al., 2013).

The correlations between stress levels, teaching time, work context and age were weak. There is no consensus in the literature about the effects of age and length of profession on stress. These variables may serve as a protective factor against depressive and stress symptoms, given the experience gained over the years, how to cope with adversity, and the improved repertoire of problem solving (Goulart \& Lipp, 2008). In contrast, some authors state that the longer the elapsed time, the greater the exposure to stressors and aggravates the stress levels presented (Pereira et al., 2014; Scandolara et al., 2015; Weber et al., 2015). Although environmental variables favor the onset of stress symptoms (Molina, Fialho, Amaral, Bach, Rocha, \& Souza, 2017), it is possible that other aspects such as personal problems that occur outside work, add to the context of work to increase the risk of stress (Reis, Fernandes, \& Gomes, 2010). Therefore, this point remains controversial, and it is possible that these differences are due to the way the research was conducted, the different stress assessment instruments applied and the type of analysis performed.

It was investigated the work context in relation to stress symptoms in teachers of public elementary school. Regarding the work context, the Work organization factor was rated moderate/critical and the others, Socio-professional relations and Working conditions were evaluated as satisfactory. The stress symptoms evaluated are close to the results of the general population, and there was no statistical difference in the comparison of stress levels between the teachers of the early and late grades. The final grade teachers scored higher on almost all EACT items, which requires attention. Among the items that presented satisfactory classification, they are included in the factor Socio-professional relations and two in Working conditions, and the highest score obtained was in the item referring to the workload. Although the literature describes that many of the items that make up EACT are indicated as risk factors for stress, no strong association was found between the factors that make up the work context and the presence of stress symptoms in this sample.

Work context is an important variable in studies of worker health. Labor activity is an important space for the construction of the identity of the working individual, enabling experiences of pleasure or suffering (Dejours \& Abdoucheli, 1994). The fact that the sample of this study has a work context assessed as moderate/critical suggests the need for care, especially in the items with the highest scores, because in the short and medium term, they may increase the negative cost of labor, leading to the worsening of psychic suffering. Socio-professional relations and Working conditions were classified as satisfactory, which reveals positive aspects that promote health and protection, which con- 
tribute to well-being at work (Mendes \& Ferreira, 2008).

Some data from EACT may have been influenced by the fatigue effect at the time the questionnaires were answered, since the research is part of a larger project and the collection was performed with several instruments on the same day. It should also be considered that the instrument does not capture variables that are specific to the teaching context, such as relationships with students, parents of students or the community in which the school is inserted.

Considering that the work context was moderate/critical, as well as the data from the detailed analysis of the most damaging items, it would already be possible to propose a plan to contain teacher exposure to these conditions. Continued exposure to moderate/critical factors tends to develop greater harm to the mental health of the worker. It is suggested to include in research agenda studies with representative samples of the teaching population and that includes the investigation of other forms of presentation of depressive and anxiety symptoms.

\section{Conflicts of Interest}

The authors declare no conflicts of interest regarding the publication of this paper.

\section{References}

Arvidsson, I., Håkansson, C., Karlson, B., Björk, J., \& Persson, R. (2016). Burnout among Swedish School Teachers: A Cross-Sectional Analysis. BMC Public Health, 16, 823. https://doi.org/10.1186/s12889-016-3498-7

Baião, L. P. M., \& Cunha, R. G. (2013). Doenças e/ou disfunções ocupacionais no meio docente: Uma revisão de literatura. Formação Docente, 5, 6-21. https://doi.org/10.15601/2237-0587/fd.v5n1p6-21

Baptista, M. N., \& Campos, D. C. (2016). Metodologia de pesquisa em ciências: Análises quantitativa e qualitativa. Rio de Janeiro: LTC.

Barbosa, A. G., Campos, R. A., \& Valentim, T. A. (2011). A diversidade em sala de aula e a relação professor-aluno. Estudos de Psicologia, 28, 453-461. https://www.redalyc.org/pdf/3953/395335660006.pdf https://doi.org/10.1590/S0103-166X2011000400006

Birolim, M. M., Mesas, A. E., González, A. D., Santos, H. G. D., Haddad, M. D. C. F. L., \& Andrade, S. M. D. (2019). Trabalho de alta exigência entre professores: Associações com fatores ocupacionais conforme o apoio social. Ciência \& Saúde Coletiva, 24, 1255-1264. https://doi.org/10.1590/1413-81232018244.08542017

Caldas, R. F., \& Hübner, M. C. (2001). O desencantamento com o aprender na escola: O que dizem professores e alunos. Psicologia: Teoria e Prática, 3, 71-82. http://editorarevistas.mackenzie.br/index.php/ptp/article/view/1091

Carlotto, M., Pizzinato, A., Fontana, C., \& Dresch, M. (2013). Avaliação e interpretação do mal-estar docente: Um estudo qualitativo sobre a Síndorme de Burnout. Mal-Estar e Subjetividade, 13, 195-220.

http://repositorio.pucrs.br/dspace/bitstream/10923/8983/2/Avaliacao_e_interpretacao_ do_mal_estar_docente_um_estudo_qualitativo_sobre_a_Sindrome_de_Burnout.pdf

Cartaxo, S. R. M., \& Martins, P. L. O. (2014). Licenciaturas e anos iniciais da Educação Básica: Uma interlocução necessária na formação de professores. Revista Diálogo 
Educacional, 14, 343-367. https://doi.org/10.7213/dialogo.educ.14.042.DS02

Ceballos, A. G. C., \& Santos, G. B. (2015). Fatores associados à dor musculoesquelética em professores: Aspectos sociodemográficos, saúde geral e bem-estar no trabalho. Revista Brasileira de Epidemiologia, 18, 702-715. https://doi.org/10.1590/1980-5497201500030015

Dalagasperina, P., \& Monteiro, J. K. (2014). Preditores da síndrome de burnoutem docente do ensino privado. Psico-USF, 19, 265-275. https://www.redalyc.org/pdf/4010/401036097012.pdf https://doi.org/10.1590/1413-82712014019002011

Dalcin, L., \& Carlotto, M. S. (2017). Síndrome de burnout em professores no Brasil: Considerações para uma agenda de pesquisa. Psicologia em Revista, 23, 745-770. https://doi.org/10.5752/P.1678-9563.2017v23n2p745-770

Dancey, C., \& Reidy, J. (2013). Estatística sem matemática para psicologia. Porto Alegre: Penso.

Dejours, C. (1988). A loucura do trabalho: Estudo de psicopatologia do trabalho. São Paulo: Cortez.

Dejours, C., \& Abdoucheli, E. (1994). Psicodinâmica do trabalho: Contribuições da escola dejouriana à análise da relação prazer, sofrimento e trabalho (pp. 119-145). São Paulo: Atlas.

Ferreira, V. T. R. (2015). Levantamento de Intensidade de Sintomas de Estresse-LIS-E. Passo Fundo: Não publicado.

Freitas, L. G., \& Facas, E. P. (2013). Vivências de prazer-sofrimento no contexto de trabalho dos professores. Estudos e Pesquisa em Psicologia, 13, 7-26.

https://www.redalyc.org/pdf/4518/451844510002.pdf https://doi.org/10.12957/epp.2013.7880

Gontijo, E. E. L., Silva, M. G., \& Inocente, N. J. (2013). Depressão na docência: Revisão de literatura. Vita et Sanitas, 7, 87-98.

Goulart, E. J., \& Lipp, M. E. (2008). Estresse entre professoras do ensino fundamental de escolas públicas estaduais. Psicologia em Estudo, 13, 847-857.

https://repositorio.unesp.br/handle/11449/8634 https://doi.org/10.1590/S1413-73722008000400023

Gouveia, L. V. (2016). As condições de trabalho e adoecimento de professores na agenda de uma entidade sindical. Saúde em Debate, 40, 206-219. https://doi.org/10.1590/0103-1104201611116

Gutierrez, L. A. C. (2016). El estrés en el profesorado. RIP: Reflexiones en psicología, 15, 75-98. http://www.scielo.org.bo/pdf/rip/n15/n15_a06.pdf

Gutierréz, L. A. C. (2017). Configuraciones categoriales respecto a fuentes de estrés en los profesores. Desafios Educativos, 17, 29-49.

http://scielo.org.bo/pdf/rip/n17/n17_a04.pdf

Hirschle, A. L. T., Gondim, S. M. G., Alberton, G. D., \& Ferreira, A. D. S. M. (2019). Estresse e bem-estar no trabalho: O papel moderador da regulação emocional. Revista Psicologia Organizações e Trabalho, 19, 532-540. https://doi.org/10.17652/rpot/2019.1.14774

Jacomini, M. A. (2010) Por que a maioria dos pais e alunos defendem a reprovação? Cadernos de Pesquisa, 40, 895-919. https://doi.org/10.1590/S0100-15742010000300012

Koch, M., Biazi, R. J., \& Benedetto, C. D. (2015). Estresse em docentes: Um estudo comparativo entre uma instituição de ensino superior pública e uma instituição de ensino superior privada na cidade de Toledo PR. Revista UNINGÁ, 21, 17-23. 
Koga, G. K., Melanda, F. N., Santos, H. G., Sant'Anna, F. L., González, A. D., Mesas, A. E., \& Andrade, S. M. (2015). Fatores associados a piores níveis da escala de Burnout em professores da educação básica. Caderno de Saúde Coletiva, 23, 268-275. https://doi.org/10.1590/1414-462X201500030121

Luft, C. D., Sanches, S. D., Mazo, G. Z., \& Andrade, A. (2007). Versão brasileira da Escala de Estresse Percebido: Tradução e validação para idosos. Revista Saúde Pública, 41, 606-615.

https://www.scielosp.org/scielo.php?pid=S0034-89102007000400015\&script=sci_arttex $\underline{\mathrm{t} \& \mathrm{t} \operatorname{lng}=\mathrm{es}}$ https://doi.org/10.1590/S0034-89102007000400015

Macaia, A. A. S., \& Fischer, F. M. (2015). Retorno ao trabalho de professores após afastamentos por transtornos mentais. Saúde e Sociedade, 24, 841-852. https://doi.org/10.1590/S0104-12902015130569

Martins, A. V., \& Honório, L. C. (2014). Prazer e sofrimento docente em uma instituição de ensino superior privada de Minas Gerais. O\&S, 21, 79-96. https://www.redalyc.org/pdf/4006/400634026005.pdf https://doi.org/10.1590/S1984-92302014000100005

Mendes, A. M. (2007). Psicodinâmica do trabalho: Teoria, método e pesquisa. São Paulo: Casa do Psicólogo.

Mendes, A. M., \& Ferreira, M. C. (2008). Contexto de Trabalho. In M. M. Siqueira (Ed.), Medidas de comportamento organizacional: Ferramentas de diagnóstico e de gestão (pp. 111-123). Porto Alegre: Artmed.

Molina, M. L., Fialho, A. R., Amaral, P. L., Bach, S. L., Rocha, L. M., \& Souza, L. D. (2017). Well-Being and Associated Factors among Elementary School Teachers in Southern Brazil. Revista CEFAC, 19, 812-820.

http://www.scielo.br/scielo.php?pid=S1516-18462017000600812\&script=sci_arttext\&tl $\underline{\mathrm{ng}}=\mathrm{pt}$ https://doi.org/10.1590/1982-021620171962217

Paschoal, T., \& Tamayo, Á. (2004). Validação da Escala de Estresse no Trabalho. Estudos de Psicologia, 9, 45-52. https://doi.org/10.1590/S1413-294X2004000100006

Pereira, É. F., Teixeira, C. S., Pelegrini, A., Meyer, C., Andrade, R., \& Lopes, A. S. (2014). Estresse relacionado ao trabalho em professores de educação básica. Ciência y Trabajo, 16, 206-210. https://scielo.conicyt.cl/pdf/cyt/v16n51/art13.pdf https://doi.org/10.4067/S0718-24492014000300013

Pereira, L., \& Silveira, L. M. D. O. B. (2017). Percepção das professoras sobre seus alunos do $5^{\circ}$ ano. Psicologia da Educação, 45, 77-86. https://doi.org/10.5935/2175-3520.20170019

Piolli, E. (2013). Política educacional e gerencialismo: Os programas e projetos da SEE-SP para a qualidade e suas implicações nas escolas, no trabalho e na saúde dos profissionais do magistério. Suplemento Pedagógico APASE.

Piolli, E., Silva, E. P., \& Heloani, J. M. (2015). Plano Nacional de Educação, autonomia controlada e adoecimento do professor. Caderno CEDES, 35, 589-607. https://doi.org/10.1590/CC0101-32622015154849

Prati, L. E., \& Eizirik, M. F. (2006). Da diversidade na passagem para a quinta série do ensino fundamental. Estudos de Psicologia, 23, 289-298.

https://doi.org/10.1590/S0103-166X2006000300008

Reis, A. P., Fernandes, S. P., \& Gomes, A. F. (2010). Estresse e fatores psicossociais. Psicologia Ciência e Profissão, 30, 712-725.

https://repositorio.ufba.br/ri/handle/ri/2951 
https://doi.org/10.1590/S1414-98932010000400004

Rey, L., Extremera, N., \& Pena, M. (2016). Emotional Competence Relating to Perceived Stress and Burnout in Spanish Teachers: A Mediator Model. PeerJ, 4, e2087. https://doi.org/10.7717/peerj.2087

Rodrigues, F. F., Paula, K. P., \& Silveira, K. A. (2017). Concepções sobre mediação da aprendizagem e relações com indicadores de estresse ocupacional. Psicologia Escolar e Educaional, 21, 253-263. https://doi.org/10.1590/2175-3539201702121112

Scandolara, T. B., Wietzikoski, E. C., Gerbasi, A. R., \& Sato, S. W. (2015). Avaliação dos níveis de estresse e depressão em professores da rede pública do município de Francisco Beltrão-PR. Arquivo Ciência e Saúde, 19, 31-38.

https://doi.org/10.25110/arqsaude.v19i1.2015.5262

Silva, N. R., Bolsoni-Silva, A. T., \& Loureiro, S. R. (2018). Burnout e depressão em professores do ensino fundamental: Um estudo correlacional. Revista Brasileira de Educação, 23, e230048. https://doi.org/10.1590/s1413-24782018230048

Silveira, K. A., Enumo, S. F., Paula, K. P., \& Batista, E. P. (2014). Estresse e enfrentamento em professores: Uma análise da literatura. Educação em Revista, 30, 15-36.

http://submission.scielo.br/index.php/edur/article/view/135049

https://doi.org/10.1590/S0102-46982014000400002

Souza, K. R. D., \& Rozemberg, B. (2013). Educational Macro-Policies and the School Management Micro-Policy: Repercussions on the Health of Workers. Educação e Pesquisa, 39, 433-447. https://doi.org/10.1590/S1517-97022013005000001

Tostes, M. V., Albuquerque, G. S., Silva, M. S., \& Petterle, R. R. (2018). Sofrimento mental de professores de ensino público. Saúde em Debate, 42, 87-99. https://doi.org/10.1590/0103-1104201811607

Vale, P. C. S. do, \& Aguillera, F. (2016). Estresse dos professores de ensino fundamental em escolas públicas: Uma revisão de literatura. Revista Psicologia, Diversidade e Saúde, 5, 86-94. https://doi.org/10.17267/2317-3394rpds.v5i1.712

Valente, A. S., Botelho, C., \& Silva, A. C. (2015). Distúrbio de voz e fatores de risco associados em professores da rede pública. Revista Brasileira de Saúde Ocupacional, 40, 183-195. https://doi.org/10.1590/0303-7657000093814

Vieira, S. L., Vidal, E. M., \& Nogueira, J. F. (2015). Gestão da aprendizagem em tempos de Ideb: Percepções dos docentes. RBPAE, 31, 85-106. https://doi.org/10.21573/vol31n12015.58916

Weber, L. D., Leite, C. R., Stasiak, G. R., Santos, C. S., \& Forteski, R. (2015). O estresse no trabalho do professor. Imagens da Educação, 5, 40-52. https://doi.org/10.4025/imagenseduc.v5i3.25789

Zibetti, M. T., \& Pereira, S. R. (2010). Mulheres e professoras: Repercussões da dupla jornada nas condições de vida e no trabalho docente. Educar em Revista, No. 2, 259-276. https://doi.org/10.1590/S0104-40602010000500016 